In the February and April issues of the Chronicle we reprinted historical reviews of the CIF/IFC by C.D. Howe (Twenty-five Years in Retrospect and Some Suggestions for the Prospect) and J.W.B. Sisam (Historical Highlights Canadian Institute of Forestry). These writers were prominent and distinguished foresters. Both were past president of the CIF and frequent contributors to the Forestry Chronicle.

In this the June issue it is not my intentioin to review the recent past twenty five years, but rather for the sake of argument to reprint an article by a non forester, non CIF member. Written in 1955 it depicts an outsiders view of forestry and foresters through the Forestry Chronicle.

I found the article blunt, accurate and well synthesized. Much of what is written applies today. Hope you find it as stimulating as I did. On yes, the author is D.M. (Doug) Fisher then a librarian in Port Arthur. Ontario. He later served as a member of Parliament in Ottawa and is now, I believe, a political correspondent.

Incidently, since I have a lot of sailing time to put in, this issue will conclude the Diamond Jubilee Column. Hope to see you all at the Sault in October.

Hugh Peacock

\section{Forestry and Foresters Through the Forestry Chronicle}

The preparation of an author-subject index to the Forestry Chronicle's first 30 volumes required me to scan all, and to partially read some, of the many editorials and articles. The Chronicle has been the product of the only national organization of foresters (first, the Canadian Society of Forest Engineers, then its successor, the Canadian Institute of Foresters); therefore, it gives an outsider the main printed source on forestry and foresters, tracing unselfconsciously the development and retrogression, scope and hopes, plaints and claims, in the field. What follows are my rather subjective impressions.

The Chronicle grew out of the NewsLetter designed to keep members informed of Society affairs and personalia. In great part the effort of Dean Howe of the Toronto Forestry School, its initiation was a wrench away from co-operation, and what some thought submersion, in the affairs

I Contributed at the request of the editor by D.M Fisher, Librarian. Forest Library of Northwestern Ontario, Lakehead Technical Institute, Port Arthur. Ontario. 31(3): 213-217. and support of the Society of American Foresters and its Journal of Forestry. The primary purpose seems to have been to create a forum where technical material relevant to applied forestry in Canada could appear and cross-fertilize foresters' ideas and methods. The covering of Society affairs, notably of the annual meetings, interlarded with technical articles and occasional ones of opinion, with a wide variety in length, presentation and quality of writing, has given the periodical a distinct unevenness. One imagines that any particular forester would rarely find it completely satisfactory reading.

One can faintly mark out five periods in the continuity. Firstly, the periodical was an effort of qualified hope until by 1929 it was well-established and attracting a fair number of good technical articles. A feature of this early period was the reprinting of material that had appeared in other places; this was to continue until very recently, reflecting the fact that foresters are rarely prolific writers. Another reflection of this latter point is the cry of editors throughout the first twenty years for material. The second period runs through the Depression to the start of the war. It was marked by a lot of vigor and sharp criticism of forestry education and forest policy.

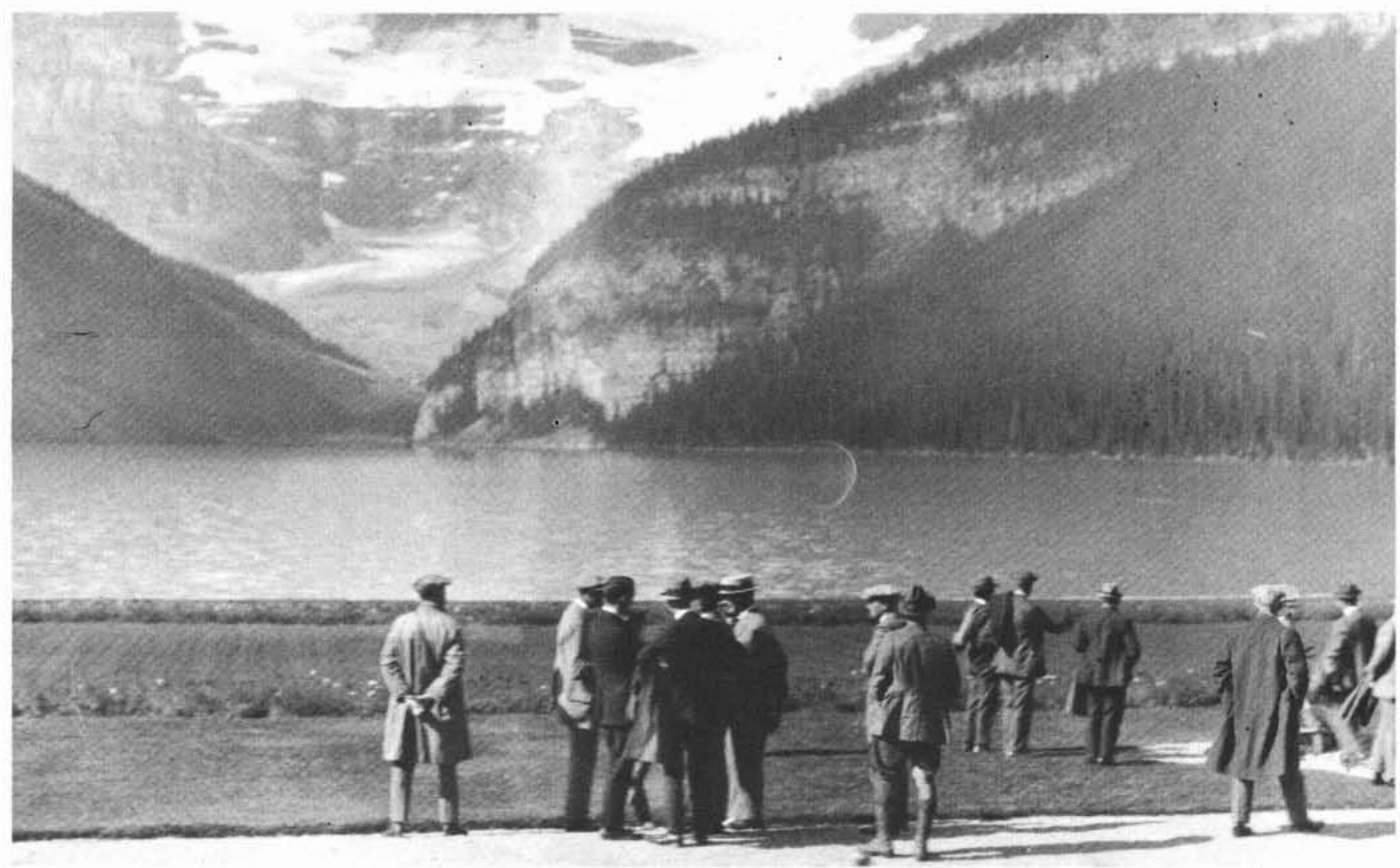

Lake Louise Meeting - Canadian Society of Forest Engineers, 1923. 
Depression seemed to have encouraged foresters to do more general thinking and to express it better than before or since. Part of this impression may come from the forthright efforts of Ellwood Wilson, editor for much of the period. Through the first two periods the major concerns seemed to be forest protection, especially fire protection, and forest inventory in all its aspects. Early on it became apparent that three regions, British Columbia, Ontario, and New Brunswick, were to make the greatest contributions to the publication and that the French-Canadian forester's part was to be a quiet one.

The third period was one of marking time during the war. The challenge of the war brought a new confidence to engineers, technically-trained men and scientists some of this seems to have rubbed off on foresters, making them more conscious and vocal on the unique features of their training and their role.

Towards the end of the war a buoyancy and hope, linked with grandiose plans for both forestry and foresters initiated a fourth period of enthusiastic ferment, excited by the post-war flood into forestry schools and a tremendous expansion of the pulp and paper industry. Shortly after we enter the ' 50 's, the influx and stimulus quietened and we are in a fifth period, what might be called an unreflective consolidation - a period which should logically end with some penetrating analysis of why the high post-war hopes for what is now popularly accepted as "the forestry profession" have had a very limited realization. The Institute is now strong in numbers, rather highly decentralized in a plethora of stronger and weaker sub-regional organizations

The increase in the number of foresters taking post-graduate work and the movement into forestry of scientific specialists from fields such as entomology, pathology, soils, genetics, photogrammetry, economics, and statistics, has increased the profundity of Chronicle articles. There has not been a compensating trend of synthesis to straddle these discrete developments in depth, in order to reach the majority of foresters. Whether this majority can follow, other than superficially, many of the articles is a moot question. One certainly doubts that they want to follow them.

While the steady rise of the pulp and paper industry to a dominant position in Canadian forest industry is in one sense a unifying development, it has set up it own compartments through the variety of forest types, logging methods, and particularized provincial legislation. The industrysponsored work of the Woodlands Section of the C.P.P.A., occasionally seeming to strain gnats in the sifting of anything relevant to any aspect of the industry, has limited, perhaps advantageously, some of the functions of the Chronicle. At the same time it has moved a majority of industrial foresters into a hierarchy where executive rank is much more authoritative than an intrinsic bond of professional men.

Despite their probable belief in free enterprise and free individualism, foresters, perhaps more than any other group, have been bound and controlled by two features of our time, monolithic industry always consolidating and merging, and monolithic government, always extending and regulating, usually as the middle power between huge corporation and hugh trade union. Usually obscured in this largely latent struggle of great powers, are the bases of interest, in this particular case, the forests - and with them the position, the creed, and the trust of the forester.

One can gather from the Chronicle that: (i) foresters have tended to bog down in the middle echelons of industry; (ii) foresters' success has been limited in impressing on administering politicians the urgency and magnitude of the forestry problem.

The first issue of the Chronicle recorded an address of Dean Howe entitled "Some aspects of our forestry problem". Almost all the "aspects" are alive today. At the core of his reasoning is the view that forestry enterprise and forest control are each linked to an annual cycle of reports and budgets whereas the trees and the forests of Canada must be related to a prospect of from 80 to 150 years. This simple but gross disparity predicates a type of long-term planning that is strange to businessmen, politicians, and the public, either as public or as individuals. It is very hard for North Americans to be purposeful within other than short-term limits. A sense of history has had an imperceptible growth in Canada, outside of Quebec. and tremendous changes in utilization have made mockery of any forestry historicism that has become vocal; for example, the obsession with the vanished pineries. All this underlines the two obvious vacuums in the content of the Forestry Chronicle. These are forest history and forest economics; that is, history and economics in inter-related terms of people. government, and industry. The ideal of democracy is the symposium where points of view meet and are reduced by discussion, not by force, to some acceptable, equitable, common denominator for action. That forestry should be part of the symposium and have a separate symposium of its own is a vital matter, largely because it touches almost every concern of our nation except that of religion. It is too easy to say that foresters are inarticulate. that their education, and subsequent isolation from each other, neither allows nor prepares them to generalize, to correlate. to take and present the overall view of their responsibilities.

Back in 1936 Ellwood Wilson touched the heart of the problem when he editorialized: "A word might be said... simply as a statement of fact about the position of the forester in public service and in the employ of large corporations. They are not free to express themselves. They not only cannot write freely about their professional work and their opinion on it, but also they cannot speak freely about public affairs". The contents of the Chronicle suggest that this is still true.

The second volume of the Chronicle printed a lengthy article entitled, "Sustained yield - its legislative basis in $\mathrm{Ca}$ - nada," by W. H. Millar. He showed that enabling legislation existed, outside of Ontario, to bring all the Canadian forests under some sort of long-term management. He wrote: "If, as has been alleged, silviculture and regulation are making no appreciable headway on public forests under technical management by trained foresters, the fault lies either with the profession of forestry or with the economic situation and not as alleged.... with the people and governments." Millar meant, of course, that the economic situation could be so desperate on the short-range for the woods industries, that long-range planning would be fantasy.

Today we know that legislation and regulation exist in every province, supposedly to direct the sustained-yield management of public, and most private, forests. Is it being used widely and effectively? Is it being used in a manner satisfactory to either industrial or government foresters? One gathers from the Chronicle that it has not, though the siiuarion is implicit, not openly argued. It is such an important theme that one cannot conceive there being too much expressed on the matter by foresters.

What does an itemized but unclassified list of general matters relevant to Canadian foresters include?

1. Professional education is concentrated in four university schools that seem to offer comparable training. These schools do not play a large part in any of their universities. They depend a great deal, perhaps too much, on the goodwill and largesse of industry not to have inhibitions on their freedom. They produce many intelligent men, able to take a valuable part in concrete tasks of industry and public administration, but few who are dynamic, articulate leaders able to gain a commanding position in either industry or government and before the public

2. There are eleven different government agencies dealing with forests and forestry in Canada. Their unevenness in quality and resources is apparent. Their existence and prerogatives postulate that any change must be piece-meal and may be retrograde.

3. Foresters are occupationally split into two main groups: industry and government. There seems to be a decided inability to understand and communicate between the groups. The industrial foresters seem to be defensively militant and over-ready to flaunt a utilitarian justification based on home-spun economics. The government foresters seem to be querulously proud of a superior ethical position which, they feel, is too often maligned and misunderstood by industry.

4. Within each of the two groups, specialization related to technical and scientific advance, makes it progressively harder for the average forester to keep informed about his profession. Further specialists in allied fields keep fragmenting forestry. 
5. The thrust of roads, the ubiquitousness of the car and leisure, continue to open up a demand for use of the forest areas This demand has great potential political power and is readily affected by popularized misinformation about the forests. It makes imperative a carefullyplanned concept of total land use which foresters show few signs of enunciating or leading.

6. The changing pattern of wood use often outdates any specific appreciation of the forestry situation before it has time to be widely understood. Further, it increases specialization, outmodes equipment and methods, and it distorts long-range marketing. In many cases it puts the onus of originating forestry change on men whose only link with the field is their treatment of the raw material.

7. Burgeoning numbers, larger expense accounts, and better salaries have enabled foresters to get together oftener. The bonhommie and éclat of these meetings seems to preclude any bitter or even extended criticism on pivotal professional matters, everyone seeking the ground of non-contention. The increasing use of panel meetings has blunted a sharpness of presentation that was never too finely honed.
8. The proliferation of regional and subregional organizations within the national body has raised the question of what goals these many small groupings are to have. At present, their function often seems to be broadly social rather than narrowly professional.

9. The great growth in publication, especially by government, and trade agencies has created overlapping and a bewildering maze of forestry literature much of it guff and slush, much of it extremely intricate, and all making demands, if we read the Chronicle rightly, on supremely-busy men. The ordinary forester writes little of it, and one suspects reads little more.

This rough delineation is unfair in its crudish, unsubstantiated, perhaps insubstantial generalities. These are impressions of an outsider who belongs to a "professional group" analogous to the foresters. Librarians, during their idealistic moments, feel they have a national mission and responsibility. They have made as slow an advance as foresters in marking out their profession and in seeing their attainments recognized by the powers of the land. Amongst librarians the following questions are debated today: What is the unique thing, if anything, that gives us a professional entity? What should be our professional standards and who should control them? Are our professional schools giving the right training? What functions should our professional society perform? How can the parts of the society find and perform specific, worth while functions? What factors prevent those of us in different aspects of the work from being frank and honest with each other? Are we honest in our mission or merely trying through group action to muscle in on our share of the swag? Should our professional journals concentrate on "how?" or "why?" Given the barriers to national outlook, should we concentrate within provincial frameworks? Canadian foresters might ask, in some cases re-open, such questions

There seems to be a current abroad in recent years, perhaps engendered by the heartiness of service clubs, that exalts those who boost and censors those who knock. Without criticism, often cutting criticism, the way is rarely cleared for construction. A society, either in macrocosm or microcosm, that is without debate, that contains no satire or corrosiveness, is usually a dull, stultefying one. It is only sixty years since Fernow propounded a forestry program in Canada, one that needs only minor remodelling today. Only sixty years. ...

\section{EDWARD S. FELLOWS \\ FORESTRY \& FOREST PRODUCTS CONSULTANT}

P.O. Box 354, 404 Queen St., FREDERICTON, N.B.

Registered Professional Forester (N.B.)

MEMBER:

Canadian Institute of Forestry

Forest Products Research Society, Etc.

\section{Woodlot Service (1978) Ltd.}

"All Matters Pertalning to Forestry"

\author{
GORDON B. YOUNG, B.Sc.F., M.F. \\ Registered Professional Forester
}

320 Maple Street

Bus.: $506-472-3396$

Fredericton, N.B.

ECONOMIC FOREST POLICY \& ADMINISTRATION 
1983 ANNUAL MEETING

CANADIAN INSTITUTE OF FORESTRY

October 3-6, 1983

Holiday Inn, Sault Ste. Marie, Ontario

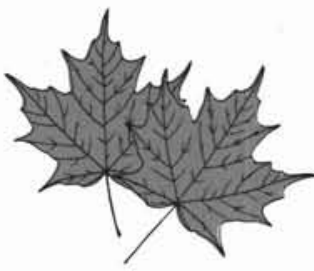

\section{THEME - FORESTRY IN CANADA: YESTERDAY - TODAY - TOMORROW \\ AN EXCELLENT CROSS-SECTION OF SPEAKERS \\ FROM CANADA'S FORESTRY COMMUNITY \\ HAS BEEN SELECTED TO MAKE THE 75TH ANNIVERSARY \\ ONE TO REMEMBER}

Theme Speaker

Blood, Sweat and Tears

(Pionner Days to World War II)

Mechanized Forestry

(World War II to Present)

Role of Forestry in

Canada's Development

(Social, Political and Economic)

Forest Management in Canada

(Practices, Objectives and Intensity)

Who Else Cares?

Canada in the Gobal

Forestry Community

(A Look at Canada's Trade Position)

Canada and the Future

Global Opportunities)

New Approaches to Forestry

in Canada

The Challenge for Canada
Mr. D. Fisher

\section{Yesterday}

\author{
Mr. E.R. Caldwell \\ Dr. C.R. Silversides \\ Dr. T.G. Honer
}

Today

Mr. F.W. McDougall

Dr. C.H. Winget

Mr. W.J.B. Devitt

Mr. D. Ogston

Mr. R. Burchell

Mr. R.F. Blanchard

Mr. W. Calow

\section{Tomorrow}

Mr. R.W. Roberts

Mr. M. Lortie

Mr. C.J. Carter

Mr. W.T. Foster

Mr. F.L.C. Reed
Journalist, Syndicated Newspaper Columnist Toronto Sun and Television Commentator

Former Ottawa District Woodlands Manager. Consolidated Bathurst

Forestry Consultant

Senior Mensurationist, Pacific Forest Research Centre. Canadian Forestry Service

Deputy Minister, Renewable Resources, Alberta Department of Energy and Natural Resources

Director General, Research and Technical Services, Canadian Forestry Service

Chief Forester, Pacific Forest Products

Past President, Ontario Federation of Anglers and Hunters

President, Sierra Club of Ontario

First Vice President, International Woodworkers of America

Policy Development and Liaison Division, Department of Industry, Trade and Commerce

Chief, Forestry Sector, Canadian International Development Agency

Professor, Université Laval

Chairman and President, Great Lakes Forest Products Limited

Deputy Minister, Ontario Ministry of Natural Resources Assistant Deputy Minister, Canadian Forestry Service 


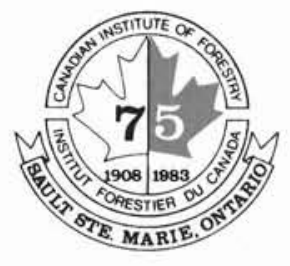

REUNION ANNUELLE 1983

INSTITUT FORESTIER DU CANADA

3-6 Octobre 1983

Holiday Inn, Sault Ste. Marie, Ontario

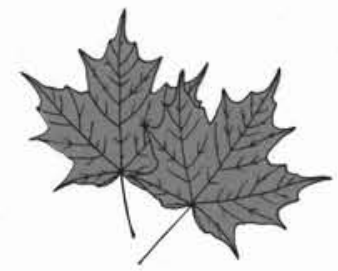

\section{THEME - LA FORESTERIE AU CANADA: HIER - AUJOURD'HUI - DEMAIN \\ UN CHOIX EXCELLENT D'ORATEURS \\ DE LA COMMUNAUTE FORESTIERE DU CANADA \\ A ETE FAIT POUR RENDRE LE 75IEME ANNIVERSAIRE \\ INOUBLIABLE}

Orateur du thème

A la sueur de son front

(Des pionniers à la

deuxième guerre mondiale)

La foresterie mécanisée

(de la duxième guerre

mondiale à nos jours)

Le rôle de la foresterie dans

le développement du Canada

(social, politique et économique)

L'aménagement forestier

au Canada (Pratiques, objectifs, intensité)

Les intéressés

Le Canada dans la communautè forestière mondiale

Le Canada et l'avenir

(les occasions mondiales)

Nouvelles façons d'aborder

l'aménagement forestier au Canada

Le défie pour le Canada
M.D. Fisher

\section{Hier}

M. E.R. Caldwell

Dr. C.R. Silversides

Dr. T.G. Honer

\section{Aujourd'hui}

M. F.W. McDougall

Dr. C. Winget

M. W.J. Devitt

M. D. Ogston

M. R. Burchell

M. R.F. Blanchard

M.W. Calow

\section{Demain}

M. R.W. Roberts
M. M. Lortie
M. C.J. Carter
M. W.T. Foster

M. F.L.C. Reed
Journaliste, collabroateur régulier du Toronto Sun et commentateur de télévision

Ancien directeur des régions boisées District d'Ottawa Consolidated-Bathurst

Conseiller forestier

Chercheur principal (Mensuration), Centre de recherche forestière du Pacifique, Service canadien des forêts

Sous-ministre, Ressources renouvelables, Ministère de l'énergie et des ressources naturelles de l'Alberta

Directeur-général, Recherches et services techniques, Service canadien des forêts

Forestier en chef, Produits forestiers du Pacifique

Ancien président, Fédération des pêcheurs et des chasseurs de l'Ontario

Président, Club Sierra de rOntario

Premier vice-président, Ouvriers du bois internationaux de l'Amérique

Planification de la politique et division de la liaison, Ministère de l'industrie et du commerce

Chef, secteur de la foresterie Agence canadienne du développement international

Professeur, Université Laval

Président et directeur, Produits forestiers des Grandslacs Itée

Sous-ministre, Ministère des richesses naturelles de I'Ontario

Sous-ministre adjoint, Service canadien des forêts 